\title{
ESTIMATION OF PRODUCTIVE VALUE OF CZECH ORIGIN SCAB-RESISTANT APPLE CULTIVARS ON DIFFERENT ROOTSTOCKS
}

\author{
Ireneusz SOSNA \\ Department of Horticulture, Wrocław University of Environmental and Life Sciences \\ Pl. Grunwaldzki 24 A, 50-363 Wroclaw, Poland
}

Received: August 6, 2014; Accepted: October 27, 2014

\begin{abstract}
Apple cultivars resistant to scab are suitable for the conventional and organic cultivation. Rootstocks impact on the growth of trees, yield and fruit quality of scab-resistant cultivars were examined in the experiment conducted at Fruit Experimental Station - Samotwór near Wrocław, during the years 1998-2008. In the spring of 1998, the trees of five Czech origin scab-resistant apple cultivars 'Rosana', 'Rubinola', 'Rajka', 'Goldstar' and 'Topaz' each on M.9, P2, P60, P16 and P22 rootstocks were planted at a spacing of $3.5 \times 1.2 \mathrm{~m}$ (2380 trees per hectare). The results of 11 -year-long studies showed that 'Rubinola' and 'Rajka' were characterised by the strongest vigour, while 'Rosana' grew much weaker. Significant differences in the cumulative yield were not observed between cultivars, but rootstocks influenced cropping instantly. Trees on rootstock P60 had biggest cross-section area and canopy volume, and the highest cumulative yield. Fruit weight was highest from trees on M9 and P60. 'Topaz' and 'Rosana' formed significantly lightest fruits and 'Goldstar' the heaviest. Trees on the super-dwarfing P22 rootstock grew and yielded very weakly and produced very small fruits. The greatest susceptibility to powdery mildew (Podosphaera leucotricha) was observed in 'Topaz' and 'Rajka'. 'Rubinola' has the best potential for organic cultivation, especially on dwarfing rootstocks.
\end{abstract}

Key words: Malus $\times$ domestica, Venturia inaequalis, resistance, rootstock

\section{INTRODUCTION}

Apple scab (Venturia inaequalis) is the most dangerous disease in apple orchards. Failure to protect against apple scab results in severe yield losses and reduces the market value of the fruits. The strategy to control apple scab relies on multiple applications of fungicides, which increases production costs and has negative impact on environment (Carisse \& Dewdney 2002). The best way to overcome these disadvantages is to cultivate scab-resistant cultivars (Sosna 2005). This is particularly important in organic cultivation, especially that for fruit processing (Czynczyk et al. 2012). Apple cultivars resistant to scab are bred in many countries all over the world. Most of them contain the gene $\operatorname{Vr}$ (at present RVIO) derived from Malus floribunda 821 (Fisher et al. 1998). In recent years there has been a growing popularity of winter cultivars of Czech origin, such as 'Rubinola', 'Rajka', 'Goldstar' and 'Topaz'. In regards to the taste, appearance and storage properties of fruits, these cultivars can compete even with 'Jonagold' (Sosna \& Kortylewska 2013). They have already been acknowledged not only in the Czech Republic, but also in other countries of Europe (Kellerhals et al. 2003; Jönsson \& Tahir 2004; Godec 2007; Lanauskas et al. 2009; Pantea 2011). Recently, in the Czech Republic, among the new scab-resistant cultivars, the largest area was planted by 'Topaz', whereas earlier 'Rosana' was the most important cultivar (Blažek \& Křelinová 2006).

Tree fruit rootstocks are used to influence precocity, tree size, fruit quality, yield efficiency, mineral uptake and to withstand adverse environmental conditions. Dwarfing rootstocks are widely used in the apple industry in Europe, the United States and 
other parts of the world (Fallahi et al. 2002). Most of the breeding programmes have sought to select dwarfing rootstocks with additional attributes, such as resistance to winter cold, weed competition, drought and soil-borne pests and diseases, but none of the currently available rootstocks combines dwarfing with all of these attributes (Webster 2002).

The aim of this study was to evaluate different combinations of scab-resistant apple cultivar/dwarf rootstock in order to match appropriate pairs of the most suitable to cultivation in the Lower Silesia region.

\section{MATERIALS AND METHODS}

The experiment was conducted at the Fruit Experimental Station at Samotwór near Wroclaw in years 1998-2008. One-year-old trees of five apple cultivars of Czech origin ('Rosana', 'Rubinola', 'Rajka', 'Goldstar' and 'Topaz') combined with each of five rootstocks - M.9, P2, P60, P16 and P22 were planted in sandy-loam soil, in the spring of 1998, at the spacing of $3.5 \times 1.2 \mathrm{~m}\left(2380\right.$ trees $\left.^{\prime} \cdot \mathrm{ha}^{-1}\right)$. The experiment was established in a randomised split-plot design in four replications, with five trees per plot (20 trees of each rootstock/cultivar combination). During the years 1998-2008, the following data were recorded: the growth of trees (expressed as trunk cross-sectional area and crown volume), the degree of infection with powdery mildew (Podosphaera leucotricha), yield and mean fruit weight. The circumference of the trunk of each tree was measured $30 \mathrm{~cm}$ above the soil level. Furthermore, the height of trees and canopy width measured in two directions were recorded. Canopy volume was calculated using a formula for cone volume. An evaluation of yield has been performed for all the trees in the subsequent years of study. To determine an average weight of a fruit, 20 randomly selected fruits were weighed for each tree. Cumulative yield efficiency (CYE) was calculated by dividing the values of cumulative yields by those referring to the tree trunk cross-sectional area in the autumn of 2008. The number of dead and bark and wood diseased trees was recorded annually and compiled at the end of the experiment. Every month, during orchard inspections shoots infected with powdery mildew were first counted and then cut off.
All trees in the experiment were trained in the form of spindle canopy with the shoots bent down by means of concrete weights until the 3 rd year after planting and pruned in May after blooming. The trees were not irrigated. Herbicides were applied in the tree rows, with grassy strips between them. The trees were fertilised with nitrogen annually and with potassium every few years, according to the recommendation for apple cultivation. Chemical pest and disease control was carried out in accordance with the current recommendations of the Orchard Protection Program, but no chemicals were used to protect the trees against apple scab. During the first 2 years after planting, no fungicides were used, afterwards fungicides against other diseases were applied only twice a year.

The obtained results were analysed statistically, using the ANOVA method (analysis of variance), for the randomised split-plot method. Significant differences at $\mathrm{p}=0.05$ were calculated using Duncan's multiple range $t$-test.

\section{RESULTS AND DISCUSSION}

Till the 11th year after planting, the cultivars and rootstocks significantly influenced the vegetative growth of trees, as well as the yield and mean fruit weight. 'Rubinola' and 'Rajka' proved to be the most vigorous cultivars, considering trunk cross-sectional area and canopy volume. The weakest growth was noted for 'Rosana' (Tables $1 \& 2$ ). These results are in accordance with the data obtained earlier by Blažek et al. (2003), Sosna (2005), Szklarz (2008), Lanauskas et al. (2009) and Pitera and Odziemkowski (2009). Blažek and Křelinová (2006) reported that the trunk cross-sectional area of 'Rosana' did not differ significantly from that of 'Topaz'. However, Ilie and Stănică (2012) evaluated 'Topaz' on rootstock M.9 as more vigorous than 'Rubinola'. On the contrary, in Kruczyńska and Rutkowski (2006) experiment a trunk crosssectional area of 'Topaz' was the smallest compared with the other cultivars. Regardless of the cultivar, the super-dwarfing P22 rootstock very strongly reduced the growth of trees. This rootstock proved to be the most suitable for very vigorous cultivars, e.g. 'Rubinola', whereas in the case of 'Rosana' the dwarfing effect of this rootstock was too strong. The 
extremely weak growth of the trees on P22 was reported by Russo et al. (2007), Piestrzeniewicz et al. (2009) and Kviklys et al. (2012). The rootstock on which trees were most vigorous in this study was P60, which confirmed reports of Czynczyk et al. (2010) and Kowalczyk and Wrona (2011). Trees on P16 grew significantly weaker in comparison to M.9. Similar results were obtained by Dierend and Bier-Kamotzke (2009), Jadczuk-Tobjasz et al. (2009) and Vercammen and Gomand (2011). How- ever, in Sosna (2013) experiment, no significant difference in trees vigour of 'Mutsu' grown on P16 and M.9 rootstocks was found.

The highest cumulative yields of 10 years were recorded in 'Topaz' and 'Rosana' trees while the lowest in 'Goldstar', but the differences among cultivars were statistically insignificant (Table 3). In comparison with the experiments of Blažek et al. (2003; Blažek (2006), the productivity of 'Topaz' was similarly high, but 'Rubinola' yield was low.

Table 1. Trunk cross-sectional area $\left(\mathrm{cm}^{2}\right)$ of 11-years-old scab-resistant apple cultivars depending on rootstock

\begin{tabular}{lllllrl}
\hline \multicolumn{1}{c}{ Cultivar/rootstock } & M.9 & P2 & P60 & P16 & P22 & Mean \\
\hline 'Rosana' & 16.4 & 20.5 & 31.1 & 16.4 & 8.8 & $18.6 \mathrm{a}$ \\
'Rubinola' & 39.5 & 38.9 & 44.7 & 23.1 & 17.1 & $32.7 \mathrm{c}$ \\
'Rajka' & 34.0 & 52.5 & 39.2 & 22.6 & 12.1 & $32.1 \mathrm{bc}$ \\
'Goldstar' & 23.9 & 16.4 & 25.7 & 20.7 & 8.4 & $19.0 \mathrm{a}$ \\
'Topaz' & 29.2 & 25.7 & 42.6 & 21.4 & 14.3 & $26.6 \mathrm{~b}$ \\
\hline Mean & $28.6 \mathrm{c}$ & $30.8 \mathrm{c}$ & $36.6 \mathrm{~d}$ & $20.8 \mathrm{~b}$ & $12.1 \mathrm{a}$ & \\
\hline LSD 0.05 cultivar*rootstock & 10.2 & & & & &
\end{tabular}

Means followed by the same letter do not differ at $\mathrm{p}=0.05$ according to Duncan's multiple range t-test

Table 2. Volume of canopy $\left(\mathrm{m}^{3}\right)$ of 11-years-old scab-resistant apple cultivars depending on rootstock

\begin{tabular}{lllllll}
\hline \multicolumn{1}{c}{ Cultivar/rootstock } & M.9 & P2 & P60 & P16 & P22 & Mean \\
\hline 'Rosana' & 1.6 & 1.6 & 2.7 & 1.5 & 0.7 & $1.6 \mathrm{a}$ \\
'Rubinola' & 3.9 & 3.2 & 4.1 & 2.7 & 1.9 & $3.2 \mathrm{c}$ \\
'Rajka' & 3.9 & 4.1 & 4.3 & 3.0 & 1.3 & $3.3 \mathrm{c}$ \\
'Goldstar' & 2.6 & 2.0 & 2.9 & 1.9 & 1.1 & $2.1 \mathrm{~b}$ \\
'Topaz' & 2.8 & 2.4 & 3.7 & 2.0 & 1.5 & $2.5 \mathrm{~b}$ \\
\hline Mean & $3.0 \mathrm{c}$ & $2.7 \mathrm{c}$ & $3.5 \mathrm{~d}$ & $2.2 \mathrm{~b}$ & $1.3 \mathrm{a}$ & \\
\hline LSD 0.05 cultivar*rootstock & n.s. & & & & &
\end{tabular}

Explanation: see table 1

Table 3. Cumulative yield during 1999-2008 $\left(\mathrm{kg} \cdot\right.$ tree $\left.^{-1}\right)$ of scab-resistant apple cultivars depending on rootstock

\begin{tabular}{lcccccc}
\hline \multicolumn{1}{c}{ Cultivar/rootstock } & M.9 & P2 & P60 & P16 & P22 & Mean \\
\hline 'Rosana' & 117.9 & 111.5 & 163.2 & 90.0 & 44.2 & $105.4 \mathrm{a}$ \\
'Rubinola' & 134.9 & 101.0 & 118.0 & 85.5 & 72.4 & $102.4 \mathrm{a}$ \\
'Rajka' & 118.4 & 120.9 & 120.0 & 95.1 & 47.3 & $100.3 \mathrm{a}$ \\
'Goldstar' & 106.2 & 81.7 & 125.8 & 79.0 & 39.7 & $86.5 \mathrm{a}$ \\
'Topaz' & 130.6 & 110.1 & 157.4 & 102.5 & 61.3 & $112.4 \mathrm{a}$ \\
\hline Mean & $121.6 \mathrm{~d}$ & $105.0 \mathrm{c}$ & $136.9 \mathrm{e}$ & $90.4 \mathrm{~b}$ & $53.0 \mathrm{a}$ & \\
\hline
\end{tabular}

$\begin{array}{ll}\mathrm{LSD}_{0.05} \text { cultivar*rootstock } & \text { n.s. } \\ \mathrm{LSD}_{0.05} \text { rootstock*cultivar } & \text { n.s. }\end{array}$

Explanation: see Table 1 
Table 4. Cumulative yield efficiency $\left(\mathrm{kg} \cdot \mathrm{cm}^{-2}\right)$ during 1998-2008 of scab-resistant apple cultivars depending on rootstock

\begin{tabular}{llllllr}
\hline \multicolumn{1}{c}{ Cultivar/rootstock } & M.9 & P2 & P60 & P16 & P22 & Mean \\
\hline 'Rosana' & 7.19 & 5.44 & 5.25 & 5.49 & 5.02 & $5.68 \mathrm{c}$ \\
'Rubinola' & 3.42 & 2.60 & 2.64 & 3.70 & 4.23 & $3.32 \mathrm{a}$ \\
'Rajka' & 3.48 & 2.30 & 3.06 & 4.21 & 3.91 & $3.39 \mathrm{a}$ \\
'Goldstar' & 4.44 & 4.98 & 4.89 & 3.82 & 4.73 & $4.57 \mathrm{~b}$ \\
'Topaz' & 4.47 & 4.28 & 3.69 & 4.79 & 4.29 & $4.30 \mathrm{~b}$ \\
\hline Mean & $4.60 \mathrm{~b}$ & $3.92 \mathrm{a}$ & $3.91 \mathrm{a}$ & $4.40 \mathrm{~b}$ & $4.44 \mathrm{~b}$ & \\
\hline LSD $_{0.05}$ cultivar*rootstock & 0.97 & & & & &
\end{tabular}

Explanation: see Table 1

Also data published by Godec (2007), Pitera and Odziemkowski (2009) and Ilie and Stănică (2012) indicate that the main weakness of 'Rubinola' is low productivity. In Kellerhals et al. (2003) study, the yielding of 'Topaz' and 'Rajka' cultivars was comparable, 'Rosana' productivity was low but ' $\mathrm{Ru}$ binola' was described as very productive. In Swedish studies (Jönsson \& Tahir 2004), the cultivar with the highest 5-year cumulative yield per tree was 'Topaz' (51 kg), followed by 'Rubinola' $(37 \mathrm{~kg}$ ) and 'Rajka' (35 kg). The lowest yield of 'Goldstar' on M.9 rootstock confirmed Czynczyk et al. (2012) results. In the study of Szklarz (2008), 'Rajka' trees grafted on M.26 rootstock seem to be more productive than 'Goldstar', 'Rosana' and 'Topaz' but the differences among these cultivars were statistically insignificant. Lower cumulative yields collected from 'Rajka' trees in this experiment could be caused by biennial fruiting, observed since the 3 rd year after planting. Differentiated impact of the studied cultivars on the yield can be explained by different climatic and soil conditions in which they were grown. Also reaction of each cultivar on specific rootstock can be different. Regardless of the cultivar, the highest yields were harvested from trees grafted on P60 and M.9 rootstocks. The lowest cumulative yield in this study was recorded from trees on very dwarfing P22. Similar results regarding P22 rootstock were reported by other authors, e.g. Chun and Fallahi (2001), Russo et al. (2007) and Kviklys et al. (2012). However, in trials of Piestrzeniewicz et al. (2009) and Czynczyk et al. (2012), trees on M.9 and P22 rootstocks had com- parable productivity, but 'Goldstar' yielded higher from trees grown on P22. In our study, trees on P16 rootstock yielded lower than those on M.9. In contrast, Jadczuk-Tobjasz et al. (2009), Czynczyk et al. (2010) and Sosna and Gudarowska (2013) reported that the productivity of apple trees grafted on P16 and M.9 rootstocks was similar, although other cultivars were evaluated. In this study, the highest CYE was recorded for weakly growing 'Rosana' and the lowest for strongly growing 'Rubinola' and 'Rajka' (Table 4). These results are similar to those of Szklarz (2008) and Lanauskas et al. (2009). The highest CYE values relating to rootstocks M.9, P22 and P16 were reported by Russo et al. (2007), Dierend and Bier-Kamotzke (2009), Piestrzeniewicz et al. (2009), Czynczyk et al. (2010) and Vercammen and Gomand (2011).

The mean fruit weight varied from $129 \mathrm{~g}-$ 'Topaz' to $159 \mathrm{~g}$ - 'Goldstar' (Table 5). Significantly smallest fruits were obtained from the most productive trees - 'Topaz' and 'Rosana'. For all cultivars tested, the mean fruit weight for the years 2000-2008 was much lower in comparison to other experiments (Blažek 2006; Kruczyńska \& Rutkowski 2006). It can be due to the fact that in our experiment trees grew in the rather light soil without irrigation and fruitlets were not thinned. The high fruit weight of the cultivar 'Goldstar' was also mentioned by other authors (Szklarz 2008; Pantea 2011). In turn, the relatively small fruits of 'Topaz' were noted by Lanauskas et al. (2009), Pitera and Odziemkowski (2009) and Suszyna (2009). The rootstocks used in this experiment had a great influ- 
ence on mean fruit weight. The trees on M.9 and P60 rootstocks had significantly heaviest fruits whereas the lightest fruits were picked from trees on rootstock P22. Similar results were reported by Chun and Fallahi (2001), Russo et al. (2007) and Dierend and Bier-Kamotzke (2009). By contrast, in Jadczuk-Tobjasz et al. (2009) experiment, 'Elise' trees grafted on P22 rootstock produced bigger fruits than those grafted on M.9. Żurawicz et al. (2013) study revealed that P60, in comparison to other rootstocks tested, significantly reduced the mean fruit weight. No differences of apple fruit weight between trees grafted on various rootstocks were found by Piestrzeniewicz et al. (2009), Kowalczyk and Wrona (2011) and Czynczyk et al. (2012).

The highest susceptibility to powdery mildew was observed on 'Topaz' trees, especially those grafted on P60 rootstock, followed by 'Rajka' (Ta- ble 6). Similar data were presented by Suszyna (2009). Shoots with powdery mildew symptoms on trees 'Rubinola', 'Goldstar' and 'Rosana' occurred only occasionally. Also in experiment of Pantea (2011), the shoots of 'Rubinola' and 'Goldstar' have not been infected by this fungus. On trees grafted on P22 was the least mildew symptoms whereas the most on trees on P60 rootstock (Table 6). None of the tested cultivar required heavy chemical protection against powdery mildew. The number of fungicide sprays was reduced to minimum and the percentage of infected shoots, even in the case of 'Topaz', was not large. The occurrence of the fungus Podosphaera leucotricha was strongly correlated with the vigour of trees. The most vigorous trees on P60 rootstock had the largest number of shoots with powdery mildew symptoms, whereas the weakly growing trees on P22 rootstock were rarely infected.

Table 5. Mean fruit weight (g) during 2000-2008 of scab-resistant apple cultivars depending on rootstock

\begin{tabular}{lcccccc}
\hline \multicolumn{1}{c}{ Cultivar/rootstock } & M.9 & P2 & P60 & P16 & P22 & Mean \\
\hline 'Rosana' & 138 & 133 & 144 & 127 & 117 & $132 \mathrm{a}$ \\
'Rubinola' & 160 & 144 & 155 & 146 & 132 & $147 \mathrm{~b}$ \\
'Rajka' & 149 & 142 & 143 & 147 & 134 & $143 \mathrm{~b}$ \\
'Goldstar' & 166 & 159 & 167 & 154 & 148 & $159 \mathrm{c}$ \\
'Topaz' & 135 & 131 & 138 & 121 & 119 & $129 \mathrm{a}$ \\
\hline Mean & $150 \mathrm{c}$ & $142 \mathrm{~b}$ & $149 \mathrm{c}$ & $139 \mathrm{~b}$ & $130 \mathrm{a}$ & \\
\hline LSD $_{0.05}$ cultivar*rootstock & n.s. & & & & &
\end{tabular}

Explanation: see Table 1

Table 6. Mean sum of shoots with apple mildew symptoms (number $\cdot \operatorname{tree}^{-1}$ ) during 2000-2008 of scab-resistant apple cultivars depending on rootstock

\begin{tabular}{lcrrrrr}
\hline \multicolumn{1}{c}{ Cultivar/rootstock } & M.9 & P2 & P60 & P16 & P22 & Mean \\
\hline 'Rosana' & 6.5 & 11.2 & 21.8 & 8.8 & 2.3 & $10.1 \mathrm{a}$ \\
'Rubinola' & 7.4 & 7.7 & 9.6 & 5.5 & 2.4 & $6.5 \mathrm{a}$ \\
'Rajka' & 46.7 & 61.9 & 54.8 & 46.1 & 7.9 & $43.5 \mathrm{~b}$ \\
'Goldstar' & 11.4 & 8.5 & 11.5 & 6.1 & 2.3 & $8.0 \mathrm{a}$ \\
'Topaz' & 75.8 & 72.0 & 136.1 & 74.0 & 23.6 & $76.3 \mathrm{c}$ \\
\hline Mean & $30.0 \mathrm{~b}$ & $32.3 \mathrm{~b}$ & $46.8 \mathrm{c}$ & $28.1 \mathrm{~b}$ & $7.7 \mathrm{a}$ & \\
\hline LSD 0.05 cultivar*rootstock & 18.5 & & & & &
\end{tabular}

Explanation: see Table 1 
Table 7. The number of lost and bark and wood diseased trees (out of 20) after 11 years of growing of scab-resistant apple cultivars depending on rootstock

\begin{tabular}{lcccccccccc}
\hline \multirow{2}{*}{ Cultivar/rootstock } & \multicolumn{4}{c}{ Dead trees } & \multicolumn{5}{c}{ Trees with diseases symptoms } \\
\cline { 2 - 12 } & M.9 & P2 & P60 & P16 & P22 & M.9 & P2 & P60 & P16 & P22 \\
\hline 'Rosana' & 0 & 2 & 0 & 0 & 2 & 0 & 0 & 0 & 1 & 0 \\
'Rubinola' & 0 & 0 & $2^{*}$ & 0 & 2 & 0 & 0 & 0 & 0 & 0 \\
'Rajka' & 0 & 1 & $2\left(1^{*}\right)$ & 2 & 3 & 0 & 0 & 0 & 0 & 2 \\
'Goldstar' & 2 & 1 & 1 & 0 & 2 & 1 & 0 & 0 & 3 & 9 \\
'Topaz' & $4\left(2^{*}\right)$ & 0 & $4\left(3^{*}\right)$ & 0 & 2 & 0 & 2 & 0 & 0 & 0 \\
\hline
\end{tabular}

* trees broken by the wind

This study shows that evaluated scab-resistant apple trees are characterised by good healthiness (Table 7). The 'Rubinola' trees were the healthiest throughout the whole period of the trial, which was also reported by Blažek et al. (2003). Jönsson and Tahir (2004) and Czynczyk et al. (2012) claimed that 'Topaz' and 'Goldstar' trees are susceptible to apple tree canker (Nectria sp.). Their results are in agreement with those obtained in this experiment. During the 11-year of the study, the most dead trees were reported on those grown on P22 rootstock. Those trees were lost mainly due to mechanical damage and bark and wood diseases, e.g. apple tree canker. On remaining rootstocks, trees were lost occasionally. Similar results were obtained by Czynczyk et al. (2010).

\section{CONCLUSIONS}

The 11-year-long experiment showed that taking into account yield, mean fruit weight and healthiness, 'Rubinola' is the most valuable scab-resistant apple cultivar in the weather and soil conditions of the Lower Silesia region. Due to excessive yields, 'Topaz' needs obligatory fruits thinning.

The trees grafted on M.9 and P60 rootstocks were very productive and also of a high quality of fruits due to their weight. For vigorous cultivars, such as 'Rubinola' and 'Rajka', the best was M.9 dwarfing rootstock, while for weaker growing cultivars 'Rosana', 'Goldstar' and 'Topaz' - semidwarfing P60. The super-dwarfing rootstock P22 proved to be completely useless for weakly growing 'Rosana'.
Among the cultivars tested, the highest susceptibility to the fungus Podosphaera leucotricha showed 'Topaz', especially when grown on P60 rootstock.

\section{REFERENCES}

Blažek J. 2006. Yields and fruit quality of 50 apple cultivars grown or tested in commercial orchards of the Czech Republic. Proc. Intern. Conference "Perspectives in European Fruit Growing", Lednice, Czech Republic, 18-20 October, pp. 47-53.

Blažek J., Křelinová J. 2006. Seven-year orchard performance of eleven new apple cultivars from Holovousy in comparison with some commonly grown ones. Hort. Sci. (Prague) 33(4): 131-139.

Blažek J., Křelinová J., Blažková J. 2003. Results of a trial with 17 chosen apple cultivars bred in the Czech Republic that was evaluated 1996-2002 at Holovousy. Věd. Pr. Ovocnáŕ. 18: 7-23.

Carisse O., Dewdney M. 2002. A review of non-fungicidal approaches for the control of apple scab. Phytoprotection 83(1): 1-29.

Chun I.J., Fallahi E. 2001. The influence of spacing and rootstock on foliar mineral nutrition and fruit quality of 'Fuji' apple trees. J. Korean Soc. Hort. Sci. 42(6): 621-624.

Czynczyk A., Bielicki P., Mika A., Krawiec A. 2012. Nine year results of growth and yielding estimation of six scab-resistant apple cultivars grafted on three dwarfing rootstocks in integrated fruit production. J. Fruit Ornam. Plant Res. 20(1): 21-28.

Czynczyk A., Bielicki P., Robinson T.L. 2010. Sevenyear evaluation of Geneva ${ }^{\circledR}$ and Polish rootstocks with 'Golden Delicious Reinders' apple in Poland. J. Am. Pom. Soc. 64(1): 42-51. http://www.pubhort.org/aps/64/v64_n1_a7.htm 
Dierend W., Bier-Kamotzke A. 2009. Influence of dwarfed apple rootstocks on growth, yield and fruit size of various varieties - Part IV: Concluding valuation. Erwerbs-obstbau 51(1): 11-19. DOI: 10.1007/s10341-009-0075-6.

Fallahi E., Colt W.M., Fallahi B., Chun I-J. 2002. The importance of apple rootstocks on tree growth, yield, fruit quality, leaf nutrition and photosynthesis with an emphasis on 'Fuji'. HortTechnology 12(1): 38-44.

Fischer C., Buttner R., Fischer M. 1998. Testing of the scab resistance stability of new resistant cultivars. Erwerbs-obstbau 40(5): 130-135.

Godec B. 2007. New varieties: Rubinola. SAD, Revija za Sadjarstvo, Vinogradništvo in Vinarstvo 18(7/8): 11.

Ilie I., Stănică F. 2012. Influence of organo-mineral fertilizers on the productivity and efficiency of an apple scab resistant varieties orchard. Scientific Papers. Series B. Horticulture LVI: 309-312.

Jadczuk-Tobjasz E., Zygmuntowska E., Szlązak R. 2009. Przydatność podkładek dla jabłoni odmiany Elise. Zesz. Prob. Post. Nauk Rol. 539: 229-237. [in Polish]

Jönsson A., Tahir I. 2004. Evaluation of scab resistant apple cultivars in Sveden. J. Fruit Ornam. Plant Res. 12 Special ed.: 223-232.

Kellerhals M., Pfister S., Husistein A., Sauer C. 2003. A field trial with scab resistant apple varieties. Obstund Weinbau 139(18): 10-13.

Kowalczyk W., Wrona D. 2011. Growth and bering of apple cultivar 'Elise' on eighteen vegetative rootstocks in „V" planting system. Acta Sci. Pol., Hortorum Cultus 10(2): 125-135.

Kruczyńska D.E., Rutkowski K.P. 2006. Quality and storage of Czech scab resistant apple cultivars. Phytopathol. Pol. 39: 53-61.

Kviklys D., Kvikliene N., Bite A., Lepsis J., Univer T., Univer N., Uselis N., Lanauskas J., Buskiene L. 2012. Baltic fruit rootstock studies: evaluation of 12 apple rootstocks in North-East Europe. Hort. Sci. (Prague) 39(1): 1-7.

Lanauskas J., Valiuškaite A., Kvikliene N., Sasnauskas A., Uselis N. 2009. Assessment of apple cultivars for organic fruit cultivation. Agronomy Res. 7 (Special issue): 363-368.

Mirzwa-Mróz E., Dzięcioł R. 2011. Brudna plamistość jabłek - choroba powszechna, ale mało znana. LIV Ogóln. Konf. Ochrony Rośl. Sadown. „Strategia ochrony upraw sadowniczych przed agrofagami w świetle aktualnych uwarunkowań ekonomiczno- środowiskowych", Ossa k. Białej Rawskiej 23-24 lutego 2011, pp. 141-144. [in Polish]

Pantea S. 2011. Study regarding the possibility to maintain apple varieties in an ecological system. Analele Univer. Din Oradea, Fascicula Protectia Mediului 17: 271-276.

Piestrzeniewicz C., Sadowski A., Dziuban R. 2009. Suitability of different dwarfing rootstocks for 'Rubin' apple trees grown in fertile soil. J. Fruit Ornam. Plant Res. 17(2): 53-62.

Pitera E., Odziemkowski S. 2009. Wartość produkcyjna odmian jabłoni odpornych na parcha w warunkach ograniczonego stosowania fungicydów. Zesz. Prob. Post. Nauk Rol. 539: 575-582. [in Polish]

Russo N.L., Robinson T.L., Fazio G., Aldwinckle H.S. 2007. Field evaluation of 64 apple rootstocks for orchard performance and fire blight resistance. HortScience 42(7): 1517-1525.

Sosna I. 2005. Growth and cropping of several scab-resistant apple cultivars on six rootstocks. Acta Sci. Pol., Hortorum Cultus 4(1): 109-118.

Sosna I., Gudarowska E. 2013. Early performance of 'Mutsu' apple trees on different rootstocks in the Lower Silesia region. Acta Sci. Pol., Hortorum Cultus 12(3): 137-146.

Sosna I., Kortylewska D. 2013. Jakość owoców kilku czeskich odmian jabłoni odpornych na parcha w zależności od podkładki. Episteme 19(3): 453-464. [in Polish]

Suszyna J. 2009. Efektywność ekologicznej uprawy jabłoni na przykładzie nasadzenia towarowego w rejonie Sandomierza. Zesz. Prob. Post. Nauk Rol. 536: 205-211. [in Polish]

Szklarz M. 2008. Productive value of seven apple cultivars with different susceptibility to apple scab (Venturia inaequalis Che.). J. Fruit Ornam. Plant Res. 16: 325-331.

Vercammen J., Gomand A. 2011. Search for a more dwarfing rootstock for 'Jonagold' apple. Acta Hort. 903: 355-362. http://www.actahort.org/books/903/903_46.htm

Webster T. 2002. Dwarfing rootstocks: past, present and future. The Compact Fruit Tree 35(3): 67-72.

Żurawicz E., Lewandowski M., Rutkowski K., Pruski K. 2013. Productivity of selected Polish scab resistant apple cultivars grown on different rootstocks. Acta Hort. 976: 141-146. http://www.actahort.org/books/976/976_17.htm 